\title{
O DASP e a Reforma Administrativa
}

\section{$D$}

E acôrdo com o anteprojeto da Lei Orgânica do Sistema Administrativo Federal, de 1963, será atribuida ao D.A.S.P. competência para dar à Reforma Administrativa o motu imprescindivel à sua efetivação, na prática.

O acêrto da proposição sobressai de plano, pois nada pode ser oposto quanto à necessidade de ser dada à Reforma a nécessária mobilidade, para que possam ser corrigidas as falhas, deficiências, inadequações e disfunções que acaso se verificarem.

Pensamos, mesmo, ser de consenso geral a certeza de que, sem o movimento, a reformação administrativa do Pais não só quedaria estática, depois de desencadeada, mas poderia, até, vir em prejuizo das próprias estruturas atuais, com a determinação de piores condiçốes de funcionamento.

O que parece não ser de consensus omnium é a entrega, ao D.A.S.P., da atribuição de dinamizar a Reforma.

A verdade, porém, é que o Departamento Administrativo do Serviço Público, além de ex-professo relativamente ao problema burocrata-administrativo brasileiro, recebe, de conformidade com o anteprojeto reformista, a força politica que the estava faltando para ser bem sucedido, vez que está colocado ao lado do Gabinete Civil e Gabinete Militar e Secretaria-Geral de Planejamento, como óryão assessor executivo da Administração Geral, da Presidência da República.

O que resta, portanto, é esperar que, aprovado o anteprojeto, seja garantido ao D.A.S.P. o estimulo e apoio de todos, desde a mais alta autoridade da Nação, ao funcionário situado na menot escala da hierarquia funcional, para que a Reforma Administrativa, de suma e urgente necessidade, seja mantida no caminho do sucesso..

Se não the fôt negado tal compreensão, apoio e estimulo, o D.A.S.P. estará apto a colaborar decidida e decisivamente para que o Brasil, dentro em pouco, ao ultrapassar a fronteira do subdesenvolvimento, conte com uma estrutura administrativa senão modelar, pelo menos com real capacidade para atender aos seus reclamos. 